\title{
Plasma Membrane Receptors Involved in the Binding and Response of Osteoclasts to Noncellular Components of the Bone
}

\author{
Divakar S. Karanth ${ }^{1}$ (D), Macey L. Martin ${ }^{1}$ and Lexie S. Holliday ${ }^{1,2, *(D)}$ \\ 1 Department of Orthodontics, College of Dentistry, University of Florida, Gainesville, FL 32610, USA; \\ dkaranth@dental.ufl.edu (D.S.K.); maceymartin@ufl.edu (M.L.M.) \\ 2 Department of Anatomy \& Cell Biology, College of Medicine, University of Florida, \\ Gainesville, FL 32610, USA \\ * Correspondence: sholliday@dental.ufl.edu
}

Citation: Karanth, D.S.; Martin, M.L.; Holliday, L.S. Plasma Membrane Receptors Involved in the Binding and Response of Osteoclasts to Noncellular Components of the Bone. Int. J. Mol. Sci. 2021, 22, 10097. https://doi.org/10.3390/ ijms221810097

Academic Editor:

Christophe Deroanne

Received: 30 June 2021

Accepted: 16 September 2021

Published: 18 September 2021

Publisher's Note: MDPI stays neutral with regard to jurisdictional claims in published maps and institutional affiliations.

Copyright: (c) 2021 by the authors. Licensee MDPI, Basel, Switzerland. This article is an open access article distributed under the terms and conditions of the Creative Commons Attribution (CC BY) license (https:// creativecommons.org/licenses/by/ $4.0 /)$.

\begin{abstract}
Osteoclasts differentiate from hematopoietic cells and resorb the bone in response to various signals, some of which are received directly from noncellular elements of the bone. In vitro, adherence to the bone triggers the reduction of cell-cell fusion events between osteoclasts and the activation of osteoclasts to form unusual dynamic cytoskeletal and membrane structures that are required for degrading the bone. Integrins on the surface of osteoclasts are known to receive regulatory signals from the bone matrix. Regulation of the availability of these signals is accomplished by enzymatic alterations of the bone matrix by protease activity and phosphorylation/dephosphorylation events. Other membrane receptors are present in osteoclasts and may interact with as yet unidentified signals in the bone. Bone mineral has been shown to have regulatory effects on osteoclasts, and osteoclast activity is also directly modulated by mechanical stress. As understanding of how osteoclasts and other bone cells interact with the bone has emerged, increasingly sophisticated efforts have been made to create bone biomimetics that reproduce both the structural properties of the bone and the bone's ability to regulate osteoclasts and other bone cells. A more complete understanding of the interactions between osteoclasts and the bone may lead to new strategies for the treatment of bone diseases and the production of bone biomimetics to repair defects.
\end{abstract}

Keywords: integrins; vacuolar $\mathrm{H}^{+}$-ATPase; V-ATPase; LRP1; bone remodeling; synaptotagmin; CD44; osteopontin; extracellular vesicles

\section{Introduction}

Bones are a stable foundation of the vertebrate body [1,2]. Barring injury or pathologies, each bone maintains shape and structural properties throughout adulthood, despite being constantly remodeled. Injury, in the form of an appendicular fracture, provides a dramatic example of the dynamism of the bone [3]. In a few weeks, as long as the ends of the bone are contained in the body and approximated, the bone will heal and even be stronger, although without proper setting and casting, the form and function may be reduced. In a pathological example, unchecked rheumatoid arthritis can trigger abnormal bone resorption and remodeling, leading to debilitating skeletal deformities [4]. In another serious pathology, certain types of cancer cells can take advantage of the normal bone dynamics by triggering abnormal bone resorption or formation, resulting in a favorable niche for cancer cells [5]. A common and serious disease arising from imbalance of bone resorption and bone formation is osteoporosis, which afflicts both women and men as they age, although women are more vulnerable. The bone is weakened due to excessive resorption compared with formation, and much morbidity and mortality result from fractures that are a consequence of a structurally compromised bone [6].

Cancellous bone turns over more slowly than trabecular bone [2]. Some regions of the skeleton are also turned over more rapidly, for example, the maxilla [7]. Others, such as 
the long bones of the arms and legs, are remodeled at a slower rate [7]. In all cases, during normal bone remodeling, the removal and replacement are performed in such a way as to maintain the strength of the existing bones, while maintaining their overall form and interactions with the joints, muscles, and other bones.

In addition, to provide structural support for vertebrates, the bone also serves as a major supply of calcium. In response to needs for circulating calcium and phosphate, resorption and formation are stimulated by regulation by the parathyroid hormone/ 1.25-hydroxyvitamin $\mathrm{D}_{3}$ signaling axis. The levels of these hormones fluctuate in response to soluble calcium and phosphate [8]. In women, estrogen also plays a role in regulating bone resorption [9]. Hormonal changes at menopause result in perimenopausal bone loss, which makes women more susceptible to osteoporotic fractures [6].

Bone remodeling is controlled by a complex web of regulators, including hormones, chemokines, and cytokines, all converging on the central regulatory molecules in bone biology - the membrane proteins, receptor activator of nuclear factor kappa B (RANK) [10,11], RANK ligand (RANKL) [12], and osteoprotegerin, a soluble protein that binds RANKL and prevents its interaction with RANK. RANK is expressed in osteoclasts and their precursors. Stimulation of RANK by RANKL, usually derived from osteocytes [13], stimulates regulatory pathways that result in osteoclastogenesis, osteoclast survival, and osteoclast bone resorptive activity [12,14-16]. As will be discussed in more detail below, recent data suggest that bone remodeling can be coupled through these molecules. Specifically, RANK in extracellular vesicles (EVs) shed by osteoclasts stimulates a RANKL reverse signaling pathway in osteoblasts, promoting bone formation [17].

Although the RANKL/RANK/osteoprotegerin signaling network is central to bone remodeling, the activity of bone cells is also controlled by their physical environment [1] This includes signals that are present in the organic elements of the bone, in the mineral component of the matrix, and in response to mechanical forces exerted on them in their bone microenvironment [1]. Together, these signals act in concert with various intercellular signals and hormones to trigger necessary bone resorption and to produce coupling factors that stimulate bone formation to replace the bone that is removed by osteoclastic resorption [18]. Although much of the regulation of osteoclasts is indirect through osteocytes [19-21], osteoblasts [19,22,23], lining cells [19] and even immune cells [15], in this review article, we will focus on what is known about the direct interaction of osteoclasts with the bone, and outstanding questions in the area.

\section{Osteoclasts: Specialized Bone-Resorbing Cells}

Osteoclasts are cells that differentiate from hematopoietic cells that are closely related to dendritic cells [24]. They are highly specialized to invade a mineralized matrix [25]. Many cells have the capacity to degrade and migrate through the matrix, which involves cytoskeletal reorganizations to form dynamic structures called podosomes (also called invadopodia), the secretion of proteases, and sometimes the acidification of the matrix [26-29]. Degradation of the bone is a very specialized version of matrix degradation. To accomplish this, basic elements involved in matrix invasion found in other cell types are further organized into higher-order structures (Figure 1). Podosomes that are very similar or identical to those found in cell types like dendritic cells, or metastatic cancer cells, are woven together to form a structure called the actin ring [26,30,31]. The actin ring presses the membrane into the bone, forcing it to conform with the bone and thereby segregating an extracellular resorption compartment [30,32]. To oppose the pushing of the membrane into the bone, osteoclasts adhere to the bone using integrins (and perhaps other matrix receptors) that bind specific ligands in the organic matrix of the bone [33-35]. 


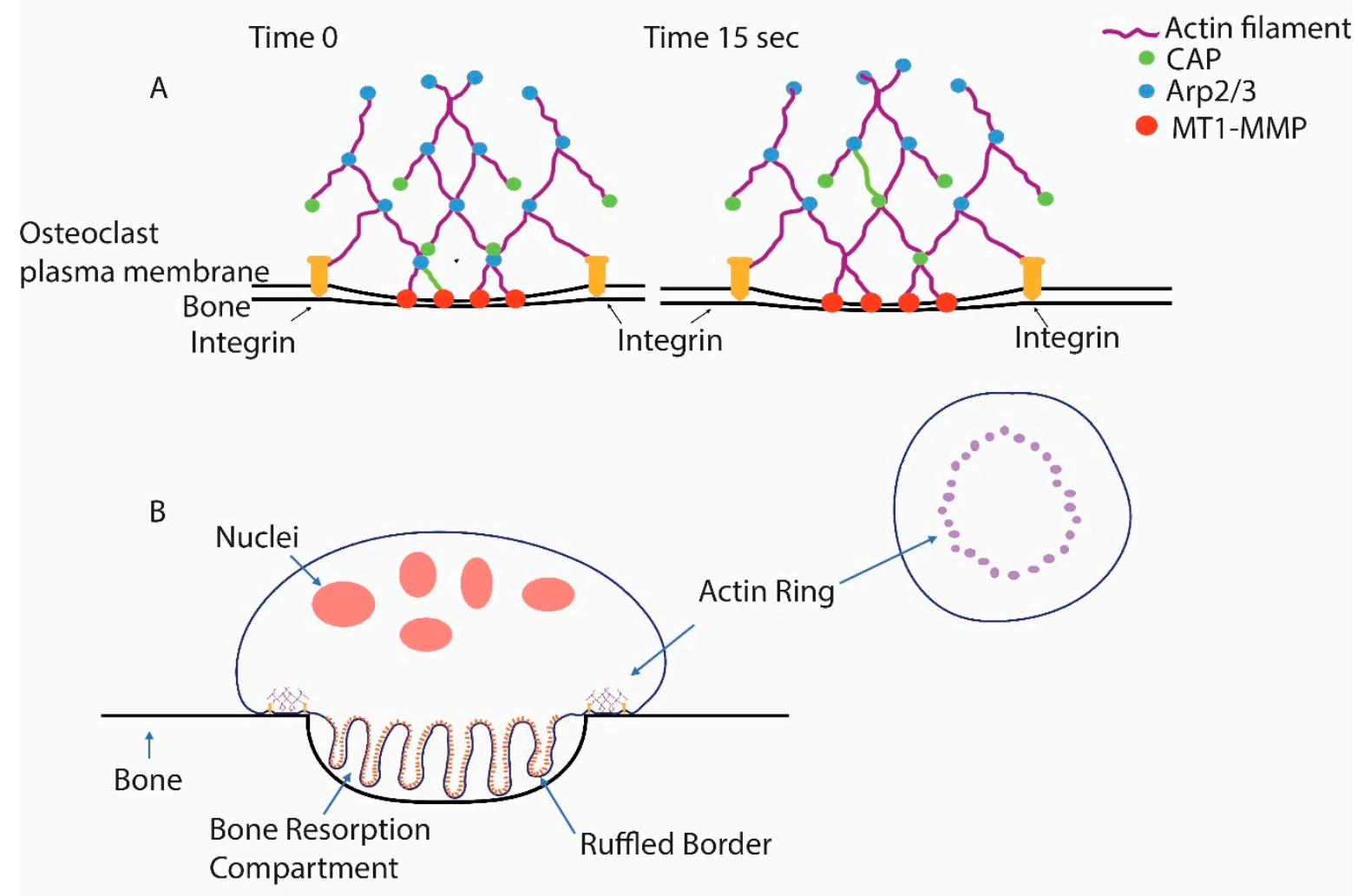

Figure 1. Podosomes are the core unit of the actin ring of osteoclasts. (A) Podosomes are discrete and dynamic microfilamentbased structures that are associated with the ability of cells to invade the extracellular matrix. Constant actin polymerization is triggered by the actin-related 2/3 (Arp2/3) complex, which binds pre-existing filaments and triggers new filament formation. Capping protein (CAP) quickly binds the growing actin filaments' end and prevents further growth, limiting the size of the individual filaments. Note that one actin filament is green and that, from time 0 to $15 \mathrm{~s}$, it has finished growing and been capped and been translocated in the filament network from the plasma membrane where it polymerized. Podosomes are connected with the less dense actin filament network of the cell, which gives them purchase as the filament polymerization exerts force on the membrane. Integrins bind the matrix and hold the cells tight against the podosomes pushing against the membrane. Membrane type 1-matrix metalloproteinase (MT1-MMP) associated with the membrane degrades matrix proteins. (B) In osteoclasts, many podosomes are woven into a higher-order structure, the actin ring. Force from the podosomes of the actin ring pushes the membrane into the bone, forming a tightly sealed extracellular resorption compartment. Vacuolar $\mathrm{H}^{+}$-ATPases (V-ATPases) are inserted, as vesicles fuse with the nascent ruffled plasma membrane, and then pump protons into the resorption compartment, lowering the $\mathrm{pH}$, solubilizing bone mineral, and providing an environment suitable for the protease activity of cathepsin $\mathrm{K}$, which is secreted into the resorption compartment and is active in acidic environments. Cathepsin $\mathrm{K}$ is the primary agent for the degradation of the organic matrix of the bone.

The plasma membrane segregated by the actin ring, called the ruffled border, is also highly specialized $[26,32,36,37]$. It is the site of the secretion of cathepsin $\mathrm{K}$, the acid cysteine proteinase primarily responsible for degrading the organic matrix of the bone [38,39]. The ruffled border is packed with vacuolar $\mathrm{H}^{+}$-ATPases (V-ATPases), which pump protons from inside of the cell into the resorption compartment $[40,41]$. The ruffled border also contains chloride voltage-gated channel 7 (CLC-7) and its subunit, osteopetrosis-associated transmembrane protein 1 (Ostm1), which are required to dissipate the charge on the membrane that results from V-ATPases' pumping of protons across the plasma membrane, and by doing so, allows sufficiently low $\mathrm{pH}$ values $(<5)$ to be achieved for bone resorption to occur [42,43]. Mutations in the a3 subunit of V-ATPase, which is selectively expressed in osteoclasts and found in the ruffle membrane [44], CLC-7 [42], or Ostm1 [45], result in autosomal malignant osteopetrosis because of dysfunctional osteoclasts that are unable to resorb the bone. 
The packing of V-ATPases into a plasma membrane domain is very atypical compared with most cells [46]. It occurs in osteoclasts, in $\alpha$-intercalated and proximal tubule cells of the kidney, and in a few other cell types [47]. In most cell types, V-ATPases, which are essential housekeeping enzymes composed of 16 subunits [48,49], are expressed at low levels and excluded from the plasma membrane [46].

In cell culture, the fate of osteoclasts is dependent on the substrate. If osteoclasts are placed on plastic or glass, many of the osteoclasts continue fusing until they become "giant" cells, which often contain hundreds of nuclei. These cells have podosomes, but they are smaller and less dynamic than the podosomes found in the actin ring of resorbing osteoclasts [50,51], and they typically surround the periphery of the cells, forming an "actin belt" (Figure 2A). In addition, although these cells have high levels of V-ATPase, they do not insert large amounts into the plasma membrane; the V-ATPase is maintained in cytosolic storage vesicles (Figure 2B) [52]. In striking contrast, the same cells, when adhering to the bone or dentine, fuse less and instead form actin rings and ruffled borders and resorb the substrate (Figure 2C,D) [46,53]. The podosomes in the actin rings are larger and more dynamic, and podosomal microfilaments are interwoven with microfilaments to make the ring structure [31,50]. Interestingly, if osteoclasts on plastic are lifted and applied to the bone, within $24 \mathrm{~h}$ no giant cells ( $>20$ nuclei) are detected, and instead, osteoclasts that rarely have more than 10 nuclei resorb the bone. One possibility is that the giant cells have undergone fission to form the smaller resorbing osteoclasts. This possibility is of particular interest because of a recent article identifying cells called "osteomorphs" that in vivo are derived from larger multinuclear osteoclasts by fission events, and which can be recycled by fusing to form larger osteoclasts [54]. These recently discovered cycles of fusion and fission were proposed to be a normal part of the life of osteoclasts in vivo. Their regulation is not understood, although the fusion events seem to require RANKL stimulation [54].

Cycles of activation followed by inactive periods have been reported $[50,55]$. One means by which activated osteoclasts can be rapidly inactivated is by treatment with inhibitors of phosphatidylinositol 3-kinase, such as wortmannin of LY294002 [53,56,57]. Inactivation involves disruption of the actin ring structure, which is coincidental with the retrieval of V-ATPase from the plasma membrane and binding between V-ATPase and microfilaments through an actin-binding domain in the B2 subunit of the V-ATPase $[53,58]$. This binding is almost certainly indicative of disassembly of V-ATPases into subdomains. The E-subunit and G-subunits form stator arms that cover the actin-binding sites in fully intact enzymes, making the interaction between the B2 subunit and microfilaments difficult to envision in the intact enzyme [48,49]. Moreover, it is well established that reversible assembly is a crucial regulatory mechanism controlling V-ATPase activity [59]. 

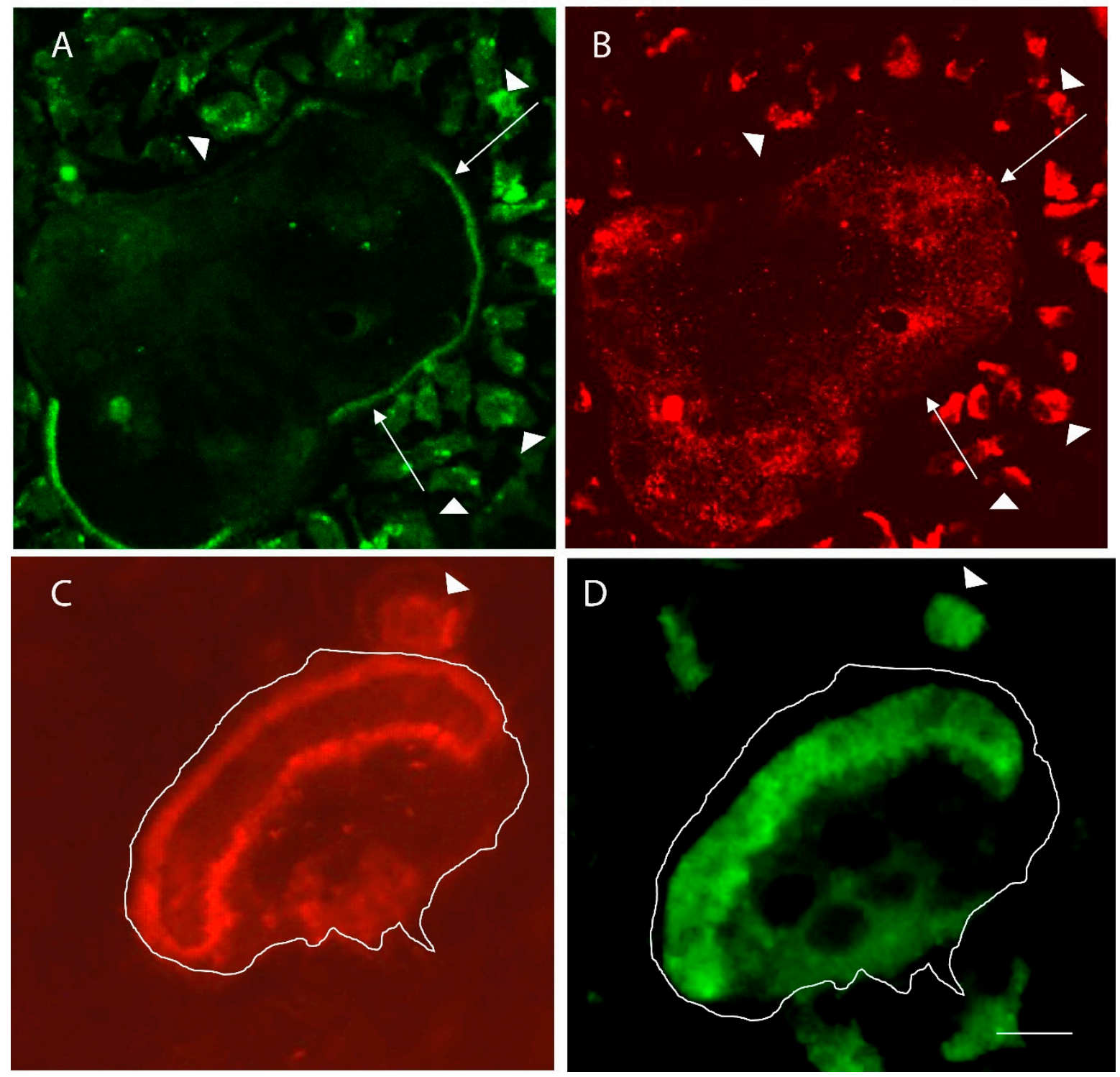

Figure 2. Comparison of inactive osteoclasts in glass substrate with resorbing osteoclasts in the bone. (A) Microfilaments, detected with phalloidin, of a large inactive osteoclast are integrated into podosomes that surround the periphery of the giant cell. Long arrows point to parts of the "actin belt" of podosomes. Arrowheads show small preosteoclasts in the area of the giant cell. (B) V-ATPase, detected with an anti-E-subunit antibody, shows the vesicular distribution in the giant cell, which is very flat (less than 2 microns thick). (C) The actin rings of two osteoclasts-the larger resorbing cell is outlined, and the arrowhead points to the actin ring of a smaller resorbing mononuclear osteoclast. (D) The V-ATPase is mostly packed into the ruffled borders of the resorbing cells, which are bounded by the actin rings. Scale bar equals $50 \mu \mathrm{m}$ in $(\mathbf{A}, \mathbf{B})$ and $10 \mu \mathrm{m}(\mathbf{C}, \mathbf{D})$.

\section{The Role of Integrins in Regulating Osteoclast Activity}

What elements of the bone stimulate the activation of osteoclasts? One instructive set of experiments examined the role of metalloproteinases and acid cysteine proteinases in bone resorption in vitro, making use of calcitriol-stimulated mouse marrow, which contains both osteoclasts and osteoblasts, and which represents a model for the bone microenvironment. It was found that the inhibition of acid cysteine proteinases (which included cathepsin K) with E64 resulted in abnormal resorption pit formation [60]. The amount of bone surface area resorbed was the same as no proteinase inhibitor vehicle controls. However, although the pits formed were demineralized, the organic matrix was not removed. In contrast, when matrix metalloproteinases, and specifically interstitial 
collagenase, were inhibited, the surface area resorbed was dramatically reduced, although the pits that were formed were normal and had both the mineral and the organic matrix removed [60]. Activation of osteoclasts was restored to control levels in the presence of the matrix metalloproteinase inhibitor by precoating bone slices with either collagen that had been cleaved by collagenase or by heat-denatured type I collagen [60]. These data suggest that cleavage of type I collagen triggered the activation of osteoclasts. When type I collagen is cleaved, it is denatured, and this exposes arginine-glycine-aspartate (RGD) sequences that are bound by certain integrins. These RGD sequences are cryptic in the native collagen. This was proposed to be the activation signal triggered by interstitial collagenase activity. Subsequent studies have provided data that are consistent with this idea [61-64].

Integrins, each of which is composed of a pair of membrane proteins designated $\alpha$ and $\beta$ [35], are central adhesion molecules allowing cells to adhere to the extracellular matrix (Figure 3A). At the same time, integrins detect signals in the matrix and respond to those signals through various signal transduction pathways [65]. There are numerous $\alpha$ and $\beta$ subunits that can associate with selected partners (Figure 3B) $[66,67]$. One important signaling molecule involved in integrin-based signaling is cellular src (c-src) [67]. This tyrosine kinase was identified as a proto-oncogene by a work, leading to a Nobel Prize for J. Michael Bishop and Harold Varmus [68]. C-src was found to accumulate at integrin adhesions and to be a crucial player in integrin-based signaling [69-72]. Because of its perceived importance, it was among the first genes to be knocked out when transgenic knockouts became possible. The knockout mice had relatively few pathologies, but they were osteopetrotic due to the failure of osteoclasts to resorb the bone properly [73-75].

A

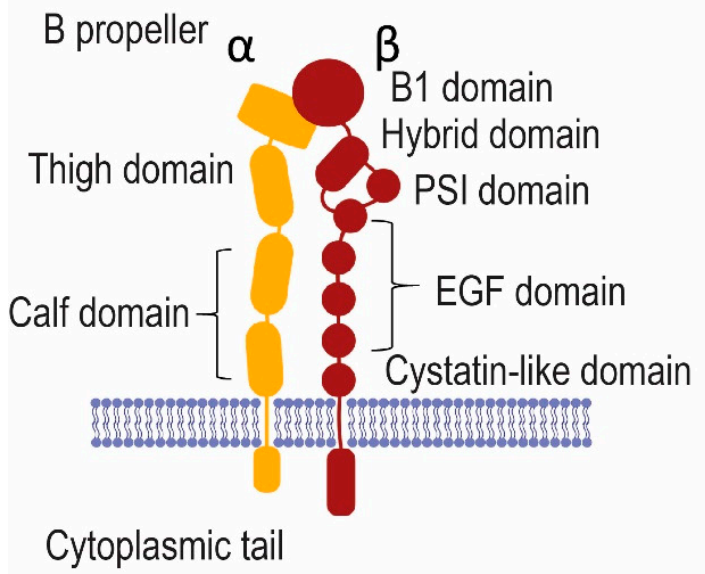

B

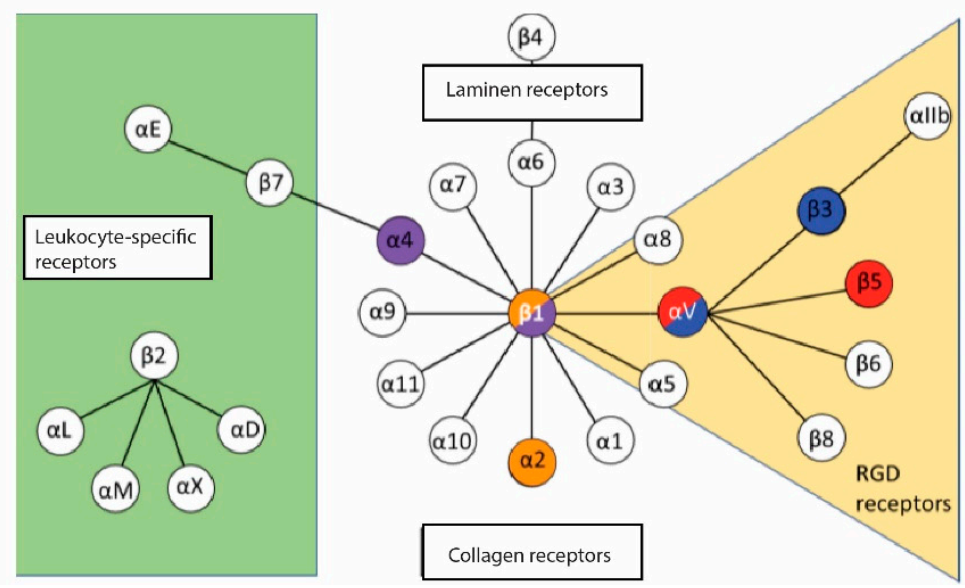

Figure 3. Integrins in osteoclasts bind to and detect signals in the bone matrix. (A) The general structure of integrins. Transmembrane $\alpha$ and $\beta$ integrin proteins pair in various ways to make integrins with various specificities and signaling properties. (B) The chart shows various integrin pairs; colored integrins are found in osteoclasts.

Osteoclasts have integrins on their plasma membrane surface (Figure 3B). $\alpha \mathrm{V} \beta 3$ integrin, which binds RGD sequences in denatured collagen and other collagen-associated matrix proteins, including osteopontin and bone sialoprotein, is strongly upregulated during osteoclastogenesis [76,77]. The interaction between $\alpha \mathrm{V} \beta 3$ integrin and its ligands is implicated in the activation of osteoclasts [76-81]. Consistent with this, mice in which $\beta 3$ integrin is knocked out are osteosclerotic, and their osteoclasts display aberrant morphology, unusual cytoskeletal organization, and reduced bone resorptive activity [82]. It is noteworthy, however, that osteoclasts lacking $\beta 3$ integrin still adhere to and resorb the bone, although less effectively. The severity of the bone disorder is partially ameliorated by three times more osteoclasts than normal being present. The lack of $\beta 3$ integrin reduces bone loss due to ovariectomy, a model for postmenopausal osteoporosis [83]. 
A specific mutation in $\beta 3$ integrin that results in Glanzmann's disease was also linked to osteopetrosis and impaired osteoclast function [84]. The primary pathology in Glanzmann's disease is thrombasthenia, the result of the absence of $\beta 3$ in platelets, resulting in their dysfunction [85].

$\alpha \mathrm{V} \beta 5$ integrins are also found in osteoclasts [86]. In contrast to $\beta 3$ integrin, knockout of $\beta 5$ integrin in mice results in increased osteoclast formation, increased bone resorptive activity, and decreased bone mineral density [87]. In addition, knockout of $\beta 5$ integrin results in increased bone loss after ovariectomy. Taken together, these data suggest that $\alpha \mathrm{V} \beta 5$ integrin is a negative regulator of osteoclastogenesis and osteoclast resorptive activity [87]. It is of interest that the two $\alpha \mathrm{V}$-containing integrins in osteoclasts, $\alpha \mathrm{V} \beta 3$ and $\alpha \mathrm{V} \beta 5$, have opposite regulatory effects on osteoclasts, even though both are thought to bind the same RGD sequences.

Osteoclasts also have large amounts of $\alpha 2 \beta 1$ integrin, which binds native collagen $[88,89]$. This leads to the idea that as the bone surface is prepared by enzymes, such as interstitial collagenase, by altering native collagen to denatured collagen, osteoclasts change from receiving signals through the $\alpha 2 \beta 1$ pathway to $\alpha \mathrm{V} \beta 3$ and $\alpha \mathrm{V} \beta 5$, and this represents a component of the activation process [81]. This would represent a version of the concept of integrin switching $[90,91]$.

\section{Identification of a Minimal Substrate Required to Stimulate Osteoclasts to Produce Actin Rings and Ruffled Borders}

Although responses by osteoclasts to matrix proteins coated onto plastic or glass can be observed, to our knowledge, there has not been a demonstration that active osteoclasts exhibiting both actin rings and V-ATPase-enriched ruffled borders occur in a nonmineralized matrix. Osteologic discs (BD Biosciences) are coated with a proprietary mineral layer, but no protein [92]. Even though osteoclasts, and also non-osteoclasts, have been shown to remove mineral from Osteologic discs [92], to our knowledge, the formation of a true ruffled border has not yet been demonstrated. Although widely used in the bone field, in our view these types of "resorption" assays must be viewed with some skepticism until documentation of V-ATPase-packed ruffled borders is provided.

RAW 264.7 osteoclast-like cells, formed by treating RAW 264.7 with recombinant RANKL, resorb Osteologic discs even though they do not (in our hands) form pits in the bone. Osteologic disc resorption has been shown by many groups. Bone resorption has been reported but is rarely convincingly verified by scanning electron microscopy. RAW 264.7 osteoclast-like cells in the bone form convincing actin rings, but have not been shown to make ruffled borders, although they insert V-ATPase into the plasma membrane [93].

We have sought to use the polymer-induced liquid precursor (PILP) process described by Gower and colleagues [94,95] to generate a minimal substrate required to stimulate both actin rings and ruffled borders [96]. This involves the use of proteins with long stretches of acidic acids, like those that occur in many noncollagenous matrix proteins associated with the bone [97]. Alternatively, a simple artificial protein consisting of a long string of polyaspartic acid can be employed. The acidic amino acids accumulate a shell of concentrated but noncrystalline $\mathrm{Ca}^{2+}$ molecules that can infiltrate a collagen matrix, which then allow calcium nanocrystals to form within the matrix [98].

When this process was used to mineralize thin slices of the demineralized bone matrix or densified collagen, the resulting bone biomimetic had calcium nanocrystals deposited in the matrix, giving it similar structural properties to slices of the bone or dentine, regardless of whether osteopontin (a noncollagenous matrix protein) or polyaspartic acid was used to drive to the PILP process [96]. However, the responses of osteoclasts to the biomimetics were strikingly different; although low levels of osteoclast activation (actin ring and ruffled border) occurred in the polyaspartic-acid-mineralized bone biomimetics, very high levels occurred in biomimetics mineralized with osteopontin [96]. This suggests that domains in osteopontin other than the polyaspartic-acid-rich domain were involved in stimulating the activation of osteoclasts in the context of the remineralized/demineralized bone matrix. 
Osteopontin has RGD sequences and serves as a ligand for $\alpha \mathrm{V} \beta 3$ integrin, and this is a good candidate to be the activation signal [80]. Osteopontin is a complex protein that can be variably modified by $\mathrm{O}$ - and $\mathrm{N}$-glycosylation, sulfation, phosphorylation, and transglutamination [99-101]. Osteopontin has a central region that contains both RGD- and non-RGD-binding sites for multiple integrins. Adjacent to the RGD motif is the sequence SLAYGLR (SVVYGLR in human), which serves as a cryptic binding site for $\alpha 4 \beta 1, \alpha 4 \beta 7$, and $\alpha 9 \beta 1$ integrins. It is masked in full-length osteopontin but is exposed following osteopontin cleavage by multiple proteases in tumors and sites of tissue injury [102,103]. Although osteoclasts have not been reported to have these integrins, we detected $\alpha 4$ integrin in extracellular vesicles shed by osteoclasts in the bone or dentine [104]. This suggests that either the osteoclasts or osteoclast precursors have $\alpha 4 \beta 1$ integrin and may detect the SLAYGLR sequence. However, knockout of $\alpha 4$ integrin does not lead to a dramatic bone phenotype $[105,106]$.

In summary, data show that integrins play a role in the activation of osteoclasts to resorb the bone. A vital element is the interaction between $\alpha \mathrm{V} \beta 3$ integrin, which is upregulated during osteoclast formation, and RGD sequences in the bone matrix. However, the fact that knockout of $\beta 3$ integrin does not completely block bone resorption [82] suggests that there are redundancies in the system. Data also suggest that osteoclasts receive negative signals from $\alpha \mathrm{V} \beta 5$ integrin and that switching from binding and stimulation through $\alpha 2 \beta 1$ integrin to $\alpha \mathrm{V} \beta 3$ may play a role in the activation process. Finally, data support the idea that integrin stimulation alone is not sufficient to account for the osteoclast activation response and may not even be required.

\section{Other Membrane Receptors Involved in Regulating Osteoclast Activation}

\subsection{CD44 and IgSF11}

CD44 is a glycosylated type I transmembrane protein that is ubiquitously expressed in higher mammals [107]. It was originally identified as a hyaluronic acid receptor and was subsequently shown to bind other extracellular matrix components, including collagen, laminin, fibronectin, and osteopontin. In various cell types, evidence has been presented that suggests that CD44 is involved in the regulation of cell adhesion, cell motility, matrix degradation, cell proliferation, and cell survival [107].

CD44 is found in osteoclasts, and studies have suggested that CD44 plays a crucial role in osteoclasts $[108,109]$. For example, in vitro it was shown to regulate osteoclast differentiation and fusion and to mediate the effects of osteopontin in osteoclasts [110]. However, transgenic knockouts of CD44 did not show a bone phenotype [111]. Knockout of CD44 enhanced cell fusion in plastic but not in the bone. More recently, CD44 was shown to have a compensatory effect on knockout of immunoglobulin superfamily 11 (IgSF11), a calcium-dependent cell-cell adhesion molecule [112]. IgSF11 knockout mice were recently shown to have high bone mass. The ability of CD44 to compensate for IgSF11 deficiency was apparently due to the interaction of both CD44 and IgSF11 with PSD-95, a scaffolding protein on the cytoplasmic face of cell adhesions [112]. These data suggest that, in osteoclasts, CD44, with its ability to interact with extracellular matrix ligands, might also interact with cell-cell adhesion molecules such as IgSF11 in the coordination of matrix binding and cell fusion. In the case of the osteoclast, where cell fusion (and fission) varies depending on the substrate, this may be a crucial regulatory activity [54]. If so, this regulation involves redundancies. Further studies will be required to examine and clarify these questions.

\subsection{Low-Density-Lipoprotein-Related Protein 1 (LRP1, Also Known as CD91 and $\alpha$-2-Macroglobulin Receptor)}

Recently, LRP1 was identified as a membrane receptor involved in osteoclast formation and bone remodeling [113-116]. LRP1 is involved in receptor-mediated endocytosis [117]. It has been linked to lipoprotein metabolism, cell motility, and neurodegenerative diseases, atherosclerosis, and certain types of cancers [118]. Osteoclast-selective knockout of LRP1, 
using the cathepsin $\mathrm{K}$ promoter to drive a cre/lox system, resulted in mice with a low bone mass phenotype [115]. In contrast, in cell culture, knockdown of LRP1 in RAW 264.7 cells yielded reduced numbers of osteoclast-like cells and reduced the inhibition of osteoblasts by the conditioned media from the knockdown cells [113].

LRP1 is first synthesized as a $600 \mathrm{kD}$ precursor, which is processed by furin to produce a $515 \mathrm{kD} \alpha$ chain and an $85 \mathrm{kD} \beta$ chain (Figure 4A) [117]. The $\alpha$ chain is the extracellular domain, and the $\beta$ chain is intracellular. In its extracellular domain, it has four distinct cysteine-rich complement-type repeats, each of which interacts with various extracellular ligands (Figure 4B). These include extracellular matrix proteins, including fibronectinand heparin-sulfate-containing proteoglycans and various proteinases, including cysteine proteinases and matrix metalloproteinases. Both proteinases complexed with inhibitors, including $\alpha$-1-antitrypsin, and uncomplexed proteinases bind LRP1. It also interacts with growth factors, including transforming growth factor $\beta$ (TGF $\beta$ ) and bone morphogenetic factor 4 (BMP4), which are involved in bone modeling and remodeling. The $\beta$ chain binds endocytic and scaffold adapters, including disabled-1, FE-65, and postsynaptic density protein [117]. These link LRP1 to membrane-bound proteins, including amyloid precursor protein, and are involved in various signal transduction pathways [118]. LRP1 can also undergo intramembranous proteolysis, which releases an extracellular LRP1 fragment and a cytosolic domain that is imported into the nucleus, where it directly regulates gene expression.

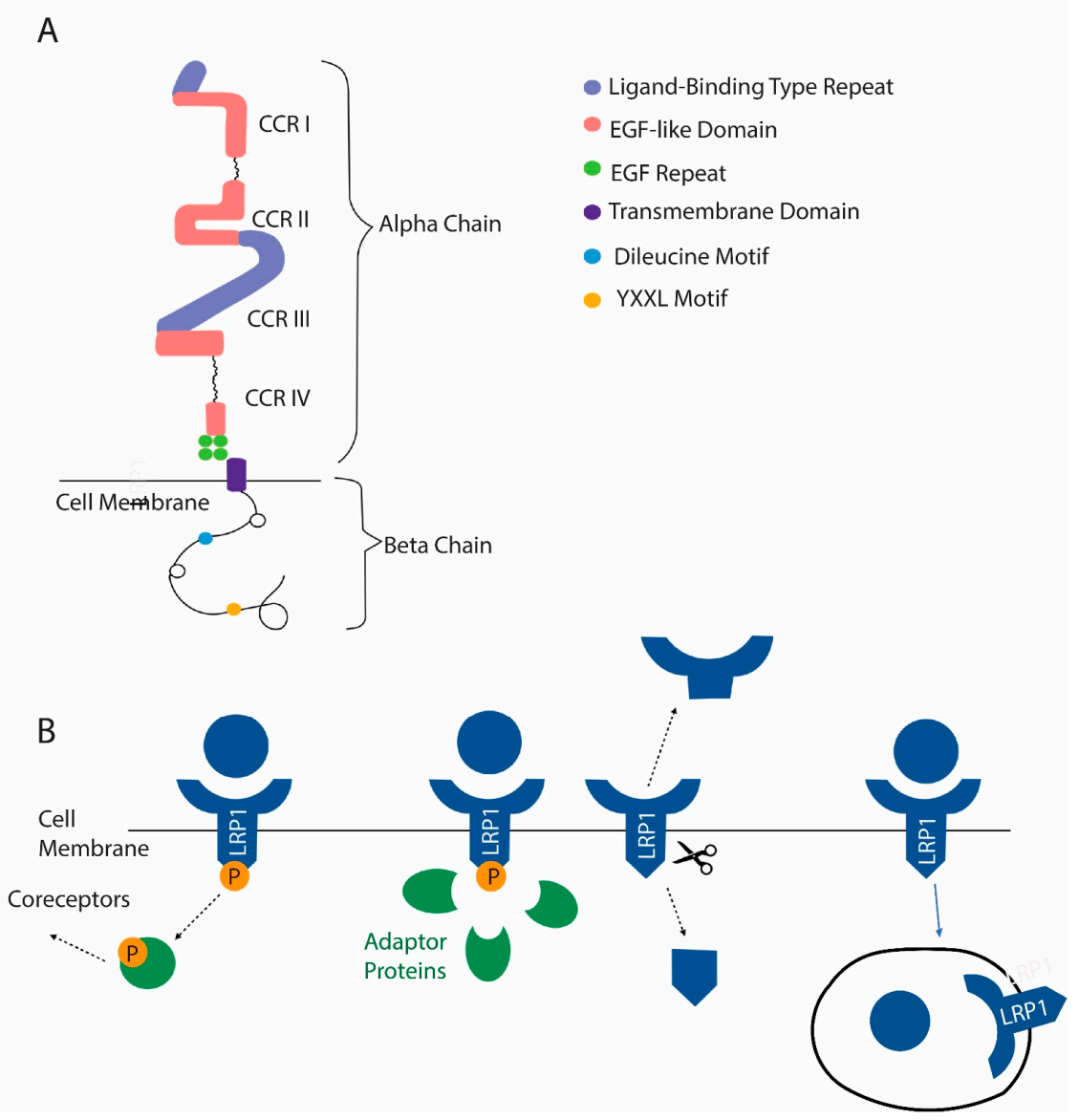

Figure 4. LRP1 is a newly identified membrane receptor with a role in osteoclast function. (A) Domain structure of LRP1. (B) Mechanisms by which LRP1 functions include the activation of coreceptors after ligand binding. The activation of signaling pathways after recruitment of adapter proteins can occur in response to ligand binding. LRP1 can be cleaved, releasing a soluble extracellular domain and a cytosolic domain that can act in the nucleus. Finally, LRP1 can act as a scavenger receptor. After certain ligands are bound, they are internalized with LRP1. 
The size and complexity of LRP1 make it challenging to study. The current data suggest that it is an important and relatively unstudied means by which osteoclasts interact with the bone.

\section{Matrix Receptors in Extracellular Vesicles (EVs) Released by Osteoclasts}

EVs, vesicles with a diameter of 30-150 nm released by cells, have recently emerged as intercellular regulators involved in bone remodeling [119]. EVs containing RANKL have been shown to stimulate osteoclast formation $[120,121]$. EVs from osteoclasts that contain RANK have been shown to regulate bone cells in vitro [122] and to couple bone resorption with bone formation in vivo [17]. Studies also suggest that EVs from osteoclasts contain microRNA-214-3p, which serves to regulate osteoblasts [123,124].

Various integrins are found in EVs shed by osteoclasts [22,104]. Integrins in EVs have been implicated in the organotropism of EVs [22,125-127]. Presumably, integrins in EVs interact with the matrix in specific organ niches such as the bone (Figure 5). Once bound to the matrix, the EVs could then interact with local cells, either through surface ligands such as RANK also present in the EVs or by fusion with cells and the delivery of membrane or luminal contents into the target cells. Integrins have also been shown to be involved in the migration of cancer cells by "decorating" the matrix with attachment sites [128-130].

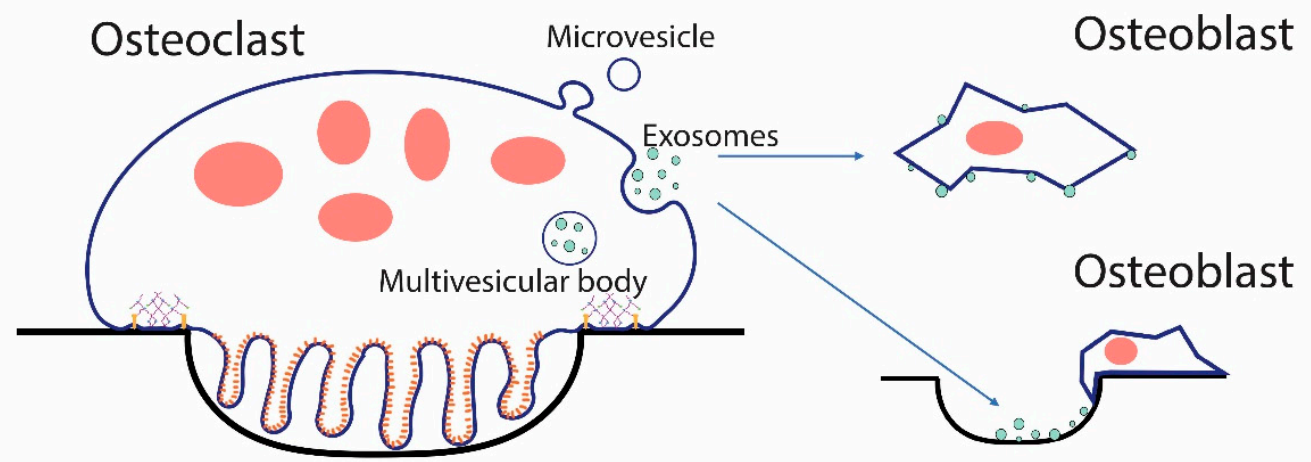

Figure 5. EVs from osteoclasts could signal osteoblasts and other cells directly, or could bind the bone or extracellular matrix serving as matrix-associated signaling units. Osteoclasts can shed two types of EVs, exosomes, which are released when the multivesicular body fuses with the plasma membrane. Microvesicles bud directly from the plasma membrane. In either case, EVs can directly interact with target cells or can bind the bone, as shown in a resorption pit above, and other forms of extracellular matrix through membrane receptors such as integrins, and the bound form can then interact with cells.

Quantitative proteomic examination of EVs shed by osteoclasts showed that LRP1 was among the most abundant proteins found [104]. LRP1 was more abundant in EVs from osteoclasts resorbing the dentine than osteoclast resorbing the bone. This suggests that like RANKL [11], and the (pro)renin receptor [131], LRP1 represents another protein where its extracellular domain can be shed as a soluble protein, or the intact protein can be shed in EVs. This opens the door to a bewildering array of possibilities for regulatory effects. For example, LRP1 in the plasma membrane might either trigger endocytosis of a proteinase or stimulate cytosolic signaling pathways. In contrast, LRP1 in an EV might bind the same proteinase, block its internalization and clearance, and, through another receptor (for example, an integrin), bind it to the matrix where the proteinase is positioned to degrade matrix proteins.

CD44 is also found in EVs released by osteoclasts and, like RANK, is enriched in EVs from osteoclasts resorbing the bone [104]. Interest in CD44 in EVs has been stimulated by the finding that CD44-containing EVs serve as a biomarker for glioblastoma [132]. In addition, specific microRNAs have been detected in the glioblastoma-derived CD44-containing EVs, and evidence was presented suggesting that these may prove to be enhanced diagnostic markers for this devastating disease [132]. Since specific microRNAs from osteoclast EVs, particularly miR-214-3p [123,124], have been implicated in their regulatory function, 
it will be of great interest to determine whether the packaging of specific microRNAs into EVs is tied to the membrane receptor content of the EVs.

\section{Calcium and Osteoclasts}

As described above, there have been many efforts to determine the minimal requirements for triggering the activation of osteoclasts, which we define as having both an actin ring and a V-ATPase-packed ruffled border. In addition to examining osteoclasts of various nonproteinaceous calcium substrates, extensive efforts testing nonmineralized substrates have been performed. To our knowledge, none has proven to be able to stimulate ruffled borders, and thus to be true osteoclast activators. For example, we were not able to show convincing evidence that activation occurred in demineralized bone, while extensive activation of osteoclasts occurred in the same matrix after it had been mineralized, making use of osteopontin to drive the PILP process [96]. Whether activation requires a stiffness of the substrate, the calcium-containing crystals, or some combination is not clear.

One challenge is that there are relatively few quality antibodies available to detect ruffled border elements (V-ATPase subunits, CLC-7, OSTM1). Often studies are conducted without this crucial piece of information. However, based on our own studies and the literature, substrates such as type I collagen, osteopontin, and other matrix proteins coated onto glass or plastic do not stimulate osteoclasts to activate. It seems likely that either because of the specific texture and rigidity of the surface due to nanocrystals of hydroxyapatite and/or because of the calcium released that calcium is required.

Dynamic video studies of live osteoclasts, containing GFP-tagged actin, "resorbing" a hydroxyapatite substrate showed that actin rings began with a patch of podosomes, which gradually opened up into the ring structure and later closed like a purse string back to a patch, which then disappeared [50]. Although in that study a ruffled border was not demonstrated, similar cytoskeletal changes, determined by images at specific time points after osteoclasts were experimentally inactivated or reactivated using phosphatidylinositol3-kinase inhibitors, occurred in resorbing osteoclasts in the bone, which tracked both microfilaments and V-ATPase [53]. In osteoclasts in the bone, podosomal patches accumulated at the same place and time as patches of V-ATPase, and likewise reuptake of $\mathrm{V}$-ATPase from the plasma membrane involved first patching of both podosomes and V-ATPase [53]. The patching of F-actin and V-ATPase could further be explained by the direct binding interaction between microfilaments and the B2 subunit of V-ATPase $[58,133]$. It is plausible that at the initial patching stage, sufficient calcium may be released by the actions of the podosomes and V-ATPase acidification to drive the expansion of the actin ring and the formation of the ruffled border due to calcium-stimulated fusion of cytosolic vesicles with the developing ruffled plasma membrane (Figure 6). This model also suggests that a calcium sensor, which is linked to vesicle fusion, is present to stimulate this process. As described below, synaptotagmin VII is a strong candidate for this role [134].

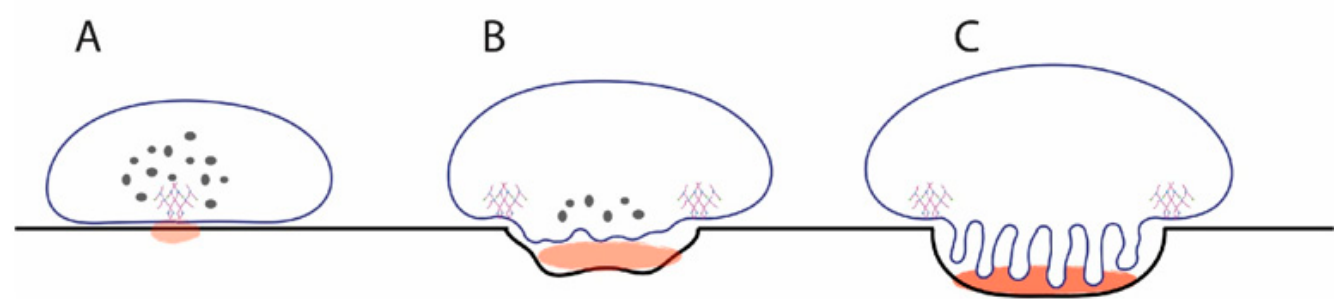

Figure 6. Model for how release of calcium at initial podosome patch could stimulate vesicle fusion to generate a ruffled border. (A) Initial patch of microfilaments and V-ATPase locally lowers $\mathrm{pH}$ sufficiently to release soluble calcium (light brown). Most V-ATPases are in cytosolic V-ATPase storage vesicles. (B) Calcium detected by synaptotagmin VII triggers fusion of cytosolic vesicles, introducing V-ATPases into the emerging ruffled border. This pumps more protons into the resorption compartment, leading to more release of soluble calcium. (C) Over time, this process continues until the mature resorption compartment of the resorbing osteoclast is formed, leaving no V-ATPase storage vesicles in the cytosol. The osteoclasts maintain low levels of other subsets of V-ATPase in the endosomal system for housekeeping functions. 
Synaptotagmin VII is one of 15 isoforms of synaptotagmin $[135,136]$. It has been shown to regulate calcium-dependent exocytosis in fibroblasts and neurons, dense-core vesicles in PC12 cells, insulin secretory granules in pancreatic islet $\beta$-cells, secretory lysosomes in cytotoxic lymphocytes, and lysosome membrane fusion in macrophages [135]. In osteoclasts, knockout of synaptotagmin VII results in osteopenia and a low bone mineral density phenotype [134]. The underlying pathology of synaptotagmin VII knockout mice was low turnover bone remodeling with less active than normal osteoclasts.

Synaptotagmin VII localizes to vesicles in the cytosol of osteoclasts, and as the osteoclasts activates, it is concentrated in the ruffled border exactly like V-ATPase and is therefore properly localized to regulate ruffled border formation through the fusion of cytosolic vesicles with the plasma membrane [134]. Despite the potential importance of this finding, many questions remain. For example, is there a direct interaction between V-ATPase and/or CLC-7 and synaptotagmin VII? The packaging of these proteins into the ruffled border suggests that this may be the case. A previous study showed that V-ATPases in the ruffled border of resorbing osteoclasts displayed strong resistance to solubilization by Triton X-100 detergent extraction, remaining coherent for $10 \mathrm{~min}$ after extraction [52]. This hints that lateral associations between V-ATPases with each other or with other proteins in the ruffled border likely play roles in the overall morphology of the ruffled border. This sort of interaction has been described for certain ATP synthases, specifically those from the mitochondria of Euglena gracilis [137]. ATP synthases in general are close relatives of V-ATPases [46].

\section{Direct Response of Osteoclasts to Mechanical Stimulation}

Mechanical strain is well known to affect the bone structure and has been extensively studied with respect to its effects on osteocytes and osteoblasts [138]. Osteocytes respond to mechanical stimulation by changes in the production of sclerostin by osteocytes, which then regulates $W N T / \beta$-catenin signaling in osteoblasts [21] as well as other signaling pathways [21]. Two routes by which osteocytes sense mechanical signaling include $\beta 1$ integrins $[139,140]$ and transient receptor potential cation channel subfamily V member 4 (TRPV4) [141], but there remain significant knowledge gaps in this area. Osteoblasts directly respond to mechanical stimulation by changes in numerous signaling networks [142], although they are less responsive than osteocytes. Osteoclasts have not been studied as extensively, but in general, it has been shown that mechanical stimulation reduces osteoclast formation and bone resorption when other factors are constant, consistent with the theme that mechanical stimulation is bone anabolic [143-145]. With the recent studies that suggest that osteoclasts are full partners, with osteoblasts and osteocytes, in signaling involved in the maintenance of the bone [18], new studies examining how mechanical signaling affects intercellular signals generated by osteoclasts are warranted.

\section{Summary}

Osteoclasts display profound responses to their substrate. Osteoclasts in the bone, dentine, and certain other mineralized surfaces undergo dramatic reorganization of their cytoskeleton and membrane trafficking machinery, leading to the formation of a resorption apparatus, which includes a ruffled border and actin ring. Integrins are known to be involved in detecting signals from the substrate that promote the activation of osteoclasts. Additional receptors in osteoclasts are likely involved in regulating activation, although their roles are less well understood. Deeper understanding of the signals that osteoclasts receive from the bone has the potential to lead to new therapeutics for modulating bone remodeling and the construction of new materials for replacement of the bone.

Author Contributions: Conceptualization, L.S.H., M.L.M. and D.S.K.; methodology, L.S.H., M.L.M. and D.S.K.; formal analysis, L.S.H., M.L.M. and D.S.K.; resources, L.S.H. and D.S.K.; data curation, L.S.H. and D.S.K.; writing—original draft preparation, L.S.H.; writing—review and editing, D.S.K.; visualization, L.S.H. and M.L.M.; funding acquisition, L.S.H., M.L.M. and D.S.K. All authors have read and agreed to the published version of the manuscript. 
Funding: This research was supported by departmental funds, University of Florida College of Dentistry, Department of Orthodontics (L.S.H., D.S.K.), and a University Scholar Fellowship (M.L.M.).

Institutional Review Board Statement: Not applicable.

Informed Consent Statement: Not applicable.

Conflicts of Interest: The authors declare no conflict of interest.

$\begin{array}{ll}\text { Abbreviations } \\ \text { Arp2/3 } & \text { Actin-related 2/3 } \\ \text { V-ATPases } & \text { Vacuolar H+-ATPases } \\ \text { CLC-7 } & \text { Chloride voltage-gated channel 7 } \\ \text { OSTM1 } & \text { Osteopetrosis-associated transmembrane protein 1 } \\ \text { RGD } & \text { Arginine-glycine-aspartic acid } \\ \text { c-src } & \text { Cellular-proto-oncogene tyrosine-protein kinase Src } \\ \text { PILP } & \text { Polymer-induced liquid precursor } \\ \text { LRP1 } & \text { LDL-receptor-related protein 1 } \\ \text { TRPV4 } & \text { Transient receptor potential cation channel subfamily V member 4 } \\ \text { EV } & \text { Extracellular vesicle } \\ \text { RANK } & \text { Receptor activator of nuclear factor kappa B } \\ \text { RANKL } & \text { Receptor activator of nuclear factor kappa B-ligand } \\ \text { MT1-MMP } & \text { Membrane type 1-matrix metalloproteinase } \\ \text { CAP } & \text { Capping protein }\end{array}$

\section{References}

1. Florencio-Silva, R.; da Silva Sasso, G.R.; Sasso-Cerri, E.; Simões, M.J.; Cerri, P.S. Biology of Bone Tissue: Structure, Function, and Factors That Influence Bone Cells. BioMed Res. Int. 2015, 2015, 421746. [CrossRef]

2. Clarke, B. Normal Bone Anatomy and Physiology. Clin. J. Am. Soc. Nephrol. 2008, 3, S131-S139. [CrossRef]

3. Einhorn, T.A.; Gerstenfeld, L.C. Fracture healing: Mechanisms and interventions. Nat. Rev. Rheumatol. 2015, 11, 45-54. [CrossRef]

4. McInnes, I.B.; Schett, G. The pathogenesis of rheumatoid arthritis. N. Engl. J. Med. 2011, 365, 2205-2219. [CrossRef]

5. Macedo, F.; Ladeira, K.; Pinho, F.; Saraiva, N.; Bonito, N.; Pinto, L.; Gonçalves, F. Bone metastases: An overview. Oncol. Rev. 2017, 11, 321. [CrossRef]

6. $\quad$ Compston, J.E.; McClung, M.R.; Leslie, W.D. Osteoporosis. Lancet 2019, 393, 364-376. [CrossRef]

7. Ristow, O.; Gerngroß, C.; Schwaiger, M.; Hohlweg-Majert, B.; Kehl, V.; Jansen, H.; Hahnefeld, L.; Otto, S.; Pautke, C. Is Bone Turnover of Jawbone and Its Possible over Suppression by Bisphosphonates of Etiologic Importance in Pathogenesis of Bisphosphonate-Related Osteonecrosis? J. Oral Maxillofac. Surg. 2014, 72, 903-910. [CrossRef]

8. DeLuca, H.F.; Vitamin, D. Historical Overview. Vitam. Horm. 2016, 100, 1-20. [CrossRef] [PubMed]

9. Levin, V.A.; Jiang, X.; Kagan, R. Estrogen therapy for osteoporosis in the modern era. Osteoporos. Int. 2018, $29,1049-1055$. [CrossRef] [PubMed]

10. Honma, M.; Ikebuchi, Y.; Suzuki, H. RANKL as a key figure in bridging between the bone and immune system: Its physiological functions and potential as a pharmacological target. Pharmacol. Ther. 2021, 218, 107682. [CrossRef] [PubMed]

11. Boyce, B.F.; Xing, L. Functions of RANKL/RANK/OPG in bone modeling and remodeling. Arch. Biochem. Biophys. 2008, 473, 139-146. [CrossRef]

12. Lacey, D.L.; Timms, E.; Tan, H.L.; Kelley, M.J.; Dunstan, C.R.; Burgess, T.; Elliott, R.; Colombero, A.; Elliott, G.; Scully, S.; et al. Osteoprotegerin ligand is a cytokine that regulates osteoclast differentiation and activation. Cell 1998, 93, 165-176. [CrossRef]

13. Xiong, J.; O'Brien, C.A. Osteocyte RANKL: New insights into the control of bone remodeling. J. Bone Miner. Res. 2012, $27,499-505$. [CrossRef] [PubMed]

14. Yasuda, H.; Shima, N.; Nakagawa, N.; Yamaguchi, K.; Kinosaki, M.; Mochizuki, S.-I.; Tomoyasu, A.; Yano, K.; Goto, M.; Murakami, A.; et al. Osteoclast differentiation factor is a ligand for osteoprotegerin/osteoclastogenesis-inhibitory factor and is identical to TRANCE/RANKL. Proc. Natl. Acad. Sci. USA 1998, 95, 3597-3602. [CrossRef] [PubMed]

15. Kong, Y.; Boyle, W.J.; Penninger, J. Osteoprotegerin ligand: A common link between osteoclastogenesis, lymph node formation and lymphocyte development. Immunol. Cell Biol. 1999, 77, 188-193. [CrossRef] [PubMed]

16. Martin, T.J.; Sims, N. RANKL/OPG; Critical role in bone physiology. Rev. Endocr. Metab. Disord. 2015, 16, 131-139. [CrossRef]

17. Ikebuchi, Y.; Aoki, S.; Honma, M.; Hayashi, M.; Sugamori, Y.; Khan, M.; Kariya, Y.; Kato, G.; Tabata, Y.; Penninger, J.; et al. Coupling of bone resorption and formation by RANKL reverse signalling. Nat. Cell Biol. 2018, 561, 195-200. [CrossRef]

18. Sims, N.A.; Martin, T.J. Osteoclasts Provide Coupling Signals to Osteoblast Lineage Cells Through Multiple Mechanisms. Annu. Rev. Physiol. 2020, 82, 507-529. [CrossRef] 
19. Marie, P.J.; Cohen-Solal, M. The Expanding Life and Functions of Osteogenic Cells: From Simple Bone-Making Cells to Multifunctional Cells and Beyond. J. Bone Miner. Res. 2018, 33, 199-210. [CrossRef]

20. De Vries, T.J.; Huesa, C. The Osteocyte as a Novel Key Player in Understanding Periodontitis Through its Expression of RANKL and Sclerostin: A Review. Curr. Osteoporos. Rep. 2019, 17, 116-121. [CrossRef]

21. Robling, A.G.; Bonewald, L.F. The Osteocyte: New Insights. Annu. Rev. Physiol. 2020, 82, 485-506. [CrossRef]

22. Holliday, L.S.; De Faria, L.P.; Rody, J.W.J. Actin and Actin-Associated Proteins in Extracellular Vesicles Shed by Osteoclasts. Int. J. Mol. Sci. 2020, 21, 158. [CrossRef] [PubMed]

23. Sims, N.A.; Martin, T.J. Coupling Signals between the Osteoclast and Osteoblast: How are Messages Transmitted between These Temporary Visitors to the Bone Surface? Front. Endocrinol. 2015, 6, 41. [CrossRef]

24. Miyamoto, T.; Ohneda, O.; Arai, F.; Iwamoto, K.; Okada, S.; Takagi, K.; Anderson, D.M.; Suda, T. Bifurcation of osteoclasts and dendritic cells from common progenitors. Blood 2001, 98, 2544-2554. [CrossRef] [PubMed]

25. Väänänen, H.K.; Laitala-Leinonen, T. Osteoclast lineage and function. Arch. Biochem. Biophys. 2008, 473, 132-138. [CrossRef] [PubMed]

26. Han, G.; Zuo, J.; Holliday, L.S. Specialized Roles for Actin in Osteoclasts: Unanswered Questions and Therapeutic Opportunities. Biomolecules 2019, 9, 17. [CrossRef] [PubMed]

27. Destaing, O.; Petropoulos, C.; Albiges-Rizo, C. Coupling between acto-adhesive machinery and ECM degradation in invadosomes. Cell Adhes. Migr. 2014, 8, 256-262. [CrossRef] [PubMed]

28. Génot, E.; Gligorijevic, B. Invadosomes in their natural habitat. Eur. J. Cell Biol. 2014, 93, 367-379. [CrossRef]

29. Seano, G.; Primo, L. Podosomes and invadopodia: Tools to breach vascular basement membrane. Cell Cycle 2015, 14, 1370-1374. [CrossRef]

30. Holtrop, M.E.; King, G.J. The ultrastructure of the osteoclast and its functional implications. Clin. Orthop. Relat. Res. 1977, 123, 177-196. [CrossRef]

31. King, G.J.; Holtrop, M.E. Actin-like filaments in bone cells of cultured mouse calvaria as demonstrated by binding to heavy meromyosin. J. Cell Biol. 1975, 66, 445-451. [CrossRef] [PubMed]

32. Vaananen, H.; Zhao, H.; Mulari, M.; Halleen, J. The cell biology of osteoclast function. J. Cell Sci. 2000, 113, $377-381$. [CrossRef] [PubMed]

33. Dresner-Pollak, R.; Rosenblatt, M. Blockade of osteoclast-mediated bone resorption through occupancy of the integrin receptor: A potential approach to the therapy of osteoporosis. J. Cell. Biochem. 1994, 56, 323-330. [CrossRef] [PubMed]

34. Kong, L.; Wang, B.; Yang, X.; He, B.; Hao, D.; Yan, L. Integrin-associated molecules and signalling cross talking in osteoclast cytoskeleton regulation. J. Cell. Mol. Med. 2020, 24, 3271-3281. [CrossRef]

35. Duong, L.T.; Rodan, G.A. Integrin-mediated signaling in the regulation of osteoclast adhesion and activation. Front Biosci. 1998, 3, 757-768. [CrossRef]

36. Helfrich, M.; Nesbitt, S.; Lakkakorpi, P.; Barnes, M.; Bodary, S.; Shankar, G.; Mason, W.; Mendrick, D.; Väänänen, H.; Horton, M. $\beta 1$ integrins and osteoclast function: Involvement in collagen recognition and bone resorption. Bone 1996, 19, 317-328. [CrossRef]

37. Mulari, M.T.K.; Zhao, H.; Lakkakorpi, P.T.; Väänänen, H.K. Osteoclast Ruffled Border Has Distinct Subdomains for Secretion and Degraded Matrix Uptake. Traffic 2003, 4, 113-125. [CrossRef]

38. Brömme, D.; Okamoto, K.; Wang, B.B.; Biroc, S. Human Cathepsin O2, a Matrix Protein-degrading Cysteine Protease Expressed in Osteoclasts. J. Biol. Chem. 1996, 271, 2126-2132. [CrossRef]

39. Everts, V.; Korper, W.; Hoeben, K.A.; Jansen, I.D.; Brömme, D.; Cleutjens, K.B.; Heeneman, S.; Peters, C.; Reinheckel, T.; Saftig, P.; et al. Osteoclastic Bone Degradation and the Role of Different Cysteine Proteinases and Matrix Metalloproteinases: Differences Between Calvaria and Long Bone. J. Bone Miner. Res. 2006, 21, 1399-1408. [CrossRef]

40. Blair, H.C.; Teitelbaum, S.; Ghiselli, R.; Gluck, S. Osteoclastic bone resorption by a polarized vacuolar proton pump. Science 1989, 245, 855-857. [CrossRef]

41. Väänänen, H.K.; Karhukorpi, E.K.; Sundquist, K.; Wallmark, B.; Roininen, I.; Hentunen, T.; Tuukkanen, J.; Lakkakorpi, P. Evidence for the presence of a proton pump of the vacuolar $\mathrm{H}(+)$-ATPase type in the ruffled borders of osteoclasts. J. Cell Biol. 1990, 111, 1305-1311. [CrossRef] [PubMed]

42. Kornak, U.; Kasper, D.; Bösl, M.R.; Kaiser, E.; Schweizer, M.; Schulz, A.; Friedrich, W.; Delling, G.; Jentsch, T.J. Loss of the ClC-7 Chloride Channel Leads to Osteopetrosis in Mice and Man. Cell 2001, 104, 205-215. [CrossRef]

43. Lange, P.; Wartosch, L.; Jentsch, T.J.; Fuhrmann, J. ClC-7 requires Ostm1 as a $\beta$-subunit to support bone resorption and lysosomal function. Nat. Cell Biol. 2006, 440, 220-223. [CrossRef]

44. Frattini, A.; Orchard, P.J.; Sobacchi, C.; Giliani, S.; Abinun, M.; Mattsson, J.P.; Keeling, D.J.; Andersson, A.-K.; Wallbrandt, P.; Zecca, L.; et al. Defects in TCIRG1 subunit of the vacuolar proton pump are responsible for a subset of human autosomal recessive osteopetrosis. Nat. Genet. 2000, 25, 343-346. [CrossRef]

45. Ramírez, A.; Faupel, J.; Goebel, I.; Stiller, A.; Beyer, S.; Stöckle, C.; Hasan, C.; Bode, U.; Kornak, U.; Kubisch, C. Identification of a novel mutation in the coding region of the grey-lethal geneOSTM1in human malignant infantile osteopetrosis. Hum. Mutat. 2004, 23, 471-476. [CrossRef] [PubMed]

46. Holliday, L.S. Vacuolar H+-ATPases (V-ATPases) as therapeutic targets: A brief review and recent developments. Biotarget 2017, 1, 18. [CrossRef]

47. Gluck, S.L.; Lee, B.S.; Wang, S.P.; Underhill, D.; Nemoto, J.; Holliday, L.S. Plasma membrane V-ATPases in proton-transporting cells of the mammalian kidney and osteoclast. Acta Physiol. Scand. Suppl. 1998, 643, 203-212. 
48. Wang, R.; Long, T.; Hassan, A.; Wang, J.; Sun, Y.; Xie, X.-S.; Li, X. Cryo-EM structures of intact V-ATPase from bovine brain. Nat. Commun. 2020, 11, 1-9. [CrossRef]

49. Abbas, Y.M.; Wu, D.; Bueler, S.A.; Robinson, C.V.; Rubinstein, J.L. Structure of V-ATPase from the mammalian brain. Science 2020, 367, 1240-1246. [CrossRef]

50. Saltel, F.; Destaing, O.; Bard, F.; Eichert, D.; Jurdic, P. Apatite-mediated Actin Dynamics in Resorbing Osteoclasts. Mol. Biol. Cell 2004, 15, 5231-5241. [CrossRef]

51. Destaing, O.; Saltel, F.; Géminard, J.-C.; Jurdic, P.; Bard, F. Podosomes Display Actin Turnover and Dynamic Self-Organization in Osteoclasts Expressing Actin-Green Fluorescent Protein. Mol. Biol. Cell 2003, 14, 407-416. [CrossRef]

52. Lee, B.S.; Gluck, S.L.; Holliday, L.S. Interaction between Vacuolar H+-ATPase and Microfilaments during Osteoclast Activation. J. Biol. Chem. 1999, 274, 29164-29171. [CrossRef] [PubMed]

53. Chen, S.-H.; Bubb, M.R.; Yarmola, E.G.; Zuo, J.; Jiang, J.; Lee, B.S.; Lu, M.; Gluck, S.L.; Hurst, I.R.; Holliday, L.S. Vacuolar H+ATPase Binding to Microfilaments: Regulation in response to phosphatidylinositol 3-kinase activity and detailed characterization of the actin-binding site in subunit B. J. Biol. Chem. 2004, 279, 7988-7998. [CrossRef] [PubMed]

54. McDonald, M.M.; Khoo, W.H.; Ng, P.Y.; Xiao, Y.; Zamerli, J.; Thatcher, P.; Kyaw, W.; Pathmanandavel, K.; Grootveld, A.K.; Moran, I.; et al. Osteoclasts recycle via osteomorphs during RANKL-stimulated bone resorption. Cell 2021, 184, 1330-1347.e13. [CrossRef] [PubMed]

55. Lakkakorpi, P.T.; Väänänen, K.H. Kinetics of the osteoclast cytoskeleton during the resorption cycle in vitro. J. Bone Miner. Res. 1991, 6, 817-826. [CrossRef] [PubMed]

56. Chellaiah, M.; Hruška, K. Osteopontin stimulates gelsolin-associated phosphoinositide levels and phosphatidylinositol triphosphate-hydroxyl kinase. Mol. Biol. Cell 1996, 7, 743-753. [CrossRef] [PubMed]

57. Nakamura, I.; Takahashi, N.; Sasaki, T.; Tanaka, S.; Udagawa, N.; Murakami, H.; Kimura, K.; Kabuyama, Y.; Kurokawa, T.; Suda, T.; et al. Wortmannin, a specific inhibitor of phosphatidylinositol-3 kinase, blocks osteoclastic bone resorption. FEBS Lett. 1995, 361, 79-84. [CrossRef]

58. Zuo, J.; Jiang, J.; Chen, S.-H.; Vergara, S.; Gong, Y.; Xue, J.; Huang, H.; Kaku, M.; Holliday, L.S. Actin Binding Activity of Subunit B of Vacuolar H+-ATPase Is Involved in Its Targeting to Ruffled Membranes of Osteoclasts. J. Bone Miner. Res. 2006, 21, 714-721. [CrossRef]

59. Kane, P.M. Regulation of V-ATPases by reversible disassembly. FEBS Lett. 2000, 469, 137-141. [CrossRef]

60. Holliday, L.S.; Welgus, H.G.; Fliszar, C.J.; Veith, G.M.; Jeffrey, J.J.; Gluck, S.L. Initiation of Osteoclast Bone Resorption by Interstitial Collagenase. J. Biol. Chem. 1997, 272, 22053-22058. [CrossRef]

61. Holliday, L.; Welgus, H.; Hanna, J.; Lee, B.; Lu, M.; Jeffrey, J.; Gluck, S. Interstitial Collagenase Activity Stimulates the Formation of Actin Rings and Ruffled Membranes in Mouse Marrow Osteoclasts. Calcif. Tissue Int. 2003, 72, 206-214. [CrossRef] [PubMed]

62. Dolce, C.; Vakani, A.; Archer, L.; Morris-Wiman, J.; Holliday, L. Effects of echistatin and an RGD peptide on orthodontic tooth movement. J. Dent. Res. 2003, 82, 682-686. [CrossRef]

63. Holliday, L.; Vakani, A.; Archer, L.; Dolce, C. Effects of Matrix Metalloproteinase Inhibitors on Bone Resorption and Orthodontic Tooth Movement. J. Dent. Res. 2003, 82, 687-691. [CrossRef]

64. Pirapaharan, D.C.; Olesen, J.B.; Andersen, T.L.; Christensen, S.B.; Kjærsgaard-Andersen, P.; Delaisse, J.-M.; Søe, K. Catabolic activity of osteoblast-lineage cells contributes to osteoclastic bone resorption in vitro. J. Cell Sci. 2019, 132, jcs.229351. [CrossRef]

65. Huveneers, S.; Danen, E. Adhesion signaling-crosstalk between integrins, Src and Rho. J. Cell Sci. 2009, 122, 1059-1069. [CrossRef]

66. Ruoslahti, E.; Reed, J.C. Anchorage dependence, integrins, and apoptosis. Cell 1994, 77, 477-478. [CrossRef]

67. Giancotti, F.G. Integrin Signaling. Science 1999, 285, 1028-1033. [CrossRef] [PubMed]

68. Parker, R.C.; Varmus, H.E.; Bishop, J.M. Cellular homologue (c-src) of the transforming gene of Rous sarcoma virus: Isolation, mapping, and transcriptional analysis of c-src and flanking regions. Proc. Natl. Acad. Sci. USA 1981, 78, 5842-5846. [CrossRef]

69. Guinebault, C.; Payrastre, B.; Racaud-Sultan, C.; Mazarguil, H.; Breton, M.; Mauco, G.; Plantavid, M.; Chap, H. Integrin-dependent translocation of phosphoinositide 3-kinase to the cytoskeleton of thrombin-activated platelets involves specific interactions of p85 alpha with actin filaments and focal adhesion kinase. J. Cell Biol. 1995, 129, 831-842. [CrossRef]

70. Schlaepfer, D.D.; Hanks, S.K.; Hunter, T.; Van Der Geer, P. Integrin-mediated signal transduction linked to Ras pathway by GRB2 binding to focal adhesion kinase. Nat. Cell Biol. 1994, 372, 786-791. [CrossRef]

71. Turner, C.; Miller, J. Primary sequence of paxillin contains putative SH2 and SH3 domain binding motifs and multiple LIM domains: Identification of a vinculin and pp125Fak-binding region. J. Cell Sci. 1994, 107, 1583-1591. [CrossRef]

72. Malosio, M.L.; De Curtis, I.; De Curtis, I. Tyrosine phosphorylation induced by integrin-mediated adhesion of retinal neurons to laminin. Int. J. Dev. Neurosci. 1996, 14, 269-281. [CrossRef]

73. Lowe, C.; Yoneda, T.; Boyce, B.F.; Chen, H.; Mundy, G.R.; Soriano, P. Osteopetrosis in Src-deficient mice is due to an autonomous defect of osteoclasts. Proc. Natl. Acad. Sci. USA 1993, 90, 4485-4489. [CrossRef]

74. Schwartzberg, P.L.; Xing, L.; Hoffmann, O.; Lowell, C.A.; Garrett, L.; Boyce, B.F.; Varmus, H.E. Rescue of osteoclast function by transgenic expression of kinase-deficient Src in src-/- mutant mice. Genes Dev. 1997, 11, 2835-2844. [CrossRef]

75. Soriano, P.; Montgomery, C.; Geske, R.; Bradley, A. Targeted disruption of the c-src proto-oncogene leads to osteopetrosis in mice. Cell 1991, 64, 693-702. [CrossRef] 
76. Miyauchi, A.; Alvarez, J.; Greenfield, E.M.; Teti, A.M.; Grano, M.; Colucci, S.; Zambonin-Zallone, A.; Ross, F.P.; Teitelbaum, S.; Cheresh, D.; et al. Binding of osteopontin to the osteoclast integrin alpha v beta 3. Osteoporos Int. 1993, 3 (Suppl. S1), 132-135. [CrossRef] [PubMed]

77. Ross, F.; Chappel, J.; Alvarez, J.; Sander, D.; Butler, W.; Farach-Carson, M.; Mintz, K.; Robey, P.; Teitelbaum, S.; Cheresh, D. Interactions between the bone matrix proteins osteopontin and bone sialoprotein and the osteoclast integrin alpha $\mathrm{v}$ beta 3 potentiate bone resorption. J. Biol. Chem. 1993, 268, 9901-9907. [CrossRef]

78. Faccio, R.; Takeshita, S.; Zallone, A.; Ross, F.P.; Teitelbaum, S.L. c-Fms and the alphavbeta3 integrin collaborate during osteoclast differentiation. J. Clin. Investig. 2003, 111, 749-758. [CrossRef]

79. Engleman, V.W.; Nickols, G.A.; Ross, F.P.; Horton, M.A.; Griggs, D.W.; Settle, S.L.; Ruminski, P.G.; Teitelbaum, S. A peptidomimetic antagonist of the alpha(v)beta3 integrin inhibits bone resorption in vitro and prevents osteoporosis in vivo. J. Clin. Investig. 1997, 99, 2284-2292. [CrossRef] [PubMed]

80. Miyauchi, A.; Alvarez, J.; Greenfield, E.; Teti, A.; Grano, M.; Colucci, S.; Zambonin-Zallone, A.; Ross, F.; Teitelbaum, S.; Cheresh, D. Recognition of osteopontin and related peptides by an alpha v beta 3 integrin stimulates immediate cell signals in osteoclasts. J. Biol. Chem. 1991, 266, 20369-20374. [CrossRef]

81. Nakamura, I.; Pilkington, M.; Lakkakorpi, P.; Lipfert, L.; Sims, S.; Dixon, S.J.; Rodan, G.; Duong, L. Role of alpha(v)beta(3) integrin in osteoclast migration and formation of the sealing zone. J. Cell Sci. 1999, 112, 3985-3993. [CrossRef] [PubMed]

82. McHugh, K.P.; Hodivala-Dilke, K.; Zheng, M.-H.; Namba, N.; Lam, J.; Novack, D.; Feng, X.; Ross, F.P.; Hynes, R.O.; Teitelbaum, S.L. Mice lacking $\beta 3$ integrins are osteosclerotic because of dysfunctional osteoclasts. J. Clin. Investig. 2000, 105, 433-440. [CrossRef] [PubMed]

83. Zhao, H.; Kitaura, H.; Sands, M.S.; Ross, F.P.; Teitelbaum, S.; Veis, D. Critical Role of $\beta 3$ Integrin in Experimental Postmenopausal Osteoporosis. J. Bone Miner. Res. 2005, 20, 2116-2123. [CrossRef] [PubMed]

84. Feng, X.; Novack, D.V.; Faccio, R.; Ory, D.S.; Aya, K.; Boyer, M.I.; McHugh, K.P.; Ross, F.P.; Teitelbaum, S.L. A Glanzmann's mutation in $\beta 3$ integrin specifically impairs osteoclast function. J. Clin. Investig. 2001, 107, 1137-1144. [CrossRef]

85. George, J.N.; Caen, J.P.; Nurden, A.T. Glanzmann's thrombasthenia: The spectrum of clinical disease. Blood 1990, 75, 1383-1395. [CrossRef] [PubMed]

86. Sago, K.; Teitelbaum, S.; Venstrom, K.; Reichardt, L.F.; Ross, F.P. The integrin alphavbeta5 is expressed on avian osteoclast precursors and regulated by retinoic acid. J. Bone Miner. Res. 1999, 14, 32-38. [CrossRef]

87. Lane, N.E.; Yao, W.; Nakamura, M.C.; Humphrey, M.B.; Kimmel, D.; Huang, X.; Sheppard, D.; Ross, F.P.; Teitelbaum, S.L. Mice Lacking the Integrin $\beta 5$ Subunit Have Accelerated Osteoclast Maturation and Increased Activity in the Estrogen-Deficient State. J. Bone Miner. Res. 2004, 20, 58-66. [CrossRef]

88. Townsend, P.A.; Villanova, I.; Teti, A.M.; Horton, M.A. $\beta 1$ Integrin antisense oligodeoxynucleotides: Utility in controlling osteoclast function. Eur. J. Cell Biol. 1999, 78, 485-496. [CrossRef]

89. Nakayamada, S.; Okada, Y.; Saito, K.; Tamura, M.; Tanaka, Y. $\beta 1$ Integrin/Focal Adhesion Kinase-mediated Signaling Induces Intercellular Adhesion Molecule 1 and Receptor Activator of Nuclear Factor кB Ligand on Osteoblasts and Osteoclast Maturation. J. Biol. Chem. 2003, 278, 45368-45374. [CrossRef] [PubMed]

90. Yamada, S.; Yamada, K.M.; Brown, K.E. Integrin regulatory switching in development: Oscillation of beta 5 integrin mRNA expression during epithelial-mesenchymal interactions in tooth development. Int. J. Dev. Biol. 1994, 38, 553-556.

91. Damsky, C.; Librach, C.; Lim, K.; Fitzgerald, M.; McMaster, M.; Janatpour, M.; Zhou, Y.; Logan, S.; Fisher, S. Integrin switching regulates normal trophoblast invasion. Development 1994, 120, 3657-3666. [CrossRef]

92. Contractor, T.; Babiarz, B.; Kowalski, A.J.; Rittling, S.R.; Sørensen, E.S.; Denhardt, D.T. Osteoclasts resorb protein-free mineral (Osteologic discs) efficiently in the absence of osteopontin. In Vivo 2005, 19, 335-341.

93. Sun-Wada, G.-H.; Wada, Y.; Futai, M. Vacuolar H+ pumping ATPases in luminal acidic organelles and extracellular compartments: Common rotational mechanism and diverse physiological roles. J. Bioenerg. Biomembr. 2003, 35, 347-358. [CrossRef] [PubMed]

94. Jee, S.-S.; Thula, T.T.; Gower, L.B. Development of bone-like composites via the polymer-induced liquid-precursor (PILP) process. Part 1: Influence of polymer molecular weight. Acta Biomater. 2010, 6, 3676-3686. [CrossRef]

95. Kim, Y.-Y.; Douglas, E.P.; Gower, L.B. Patterning Inorganic $\left(\mathrm{CaCO}_{3}\right)$ Thin Films via a Polymer-Induced Liquid-Precursor Process. Langmuir 2007, 23, 4862-4870. [CrossRef] [PubMed]

96. Rodriguez, D.E.; Thula-Mata, T.; Toro, E.J.; Yeh, Y.-W.; Holt, C.; Holliday, L.S.; Gower, L.B. Multifunctional role of osteopontin in directing intrafibrillar mineralization of collagen and activation of osteoclasts. Acta Biomater. 2014, 10, $494-507$. [CrossRef] [PubMed]

97. Thula, T.T.; Svedlund, F.; Rodriguez, D.E.; Podschun, J.; Pendi, L.; Gower, L.B. Mimicking the Nanostructure of Bone: Comparison of Polymeric Process-Directing Agents. Polymers 2010, 3, 10-35. [CrossRef]

98. Gower, L.B. Biomimetic Model Systems for Investigating the Amorphous Precursor Pathway and Its Role in Biomineralization. Chem. Rev. 2008, 108, 4551-4627. [CrossRef]

99. Boskey, A.L. Osteopontin and Related Phosphorylated Sialoproteins: Effects on Mineralization. Ann. N. Y. Acad. Sci. 1995, 760, 249-256. [CrossRef] [PubMed]

100. Si, J.; Wang, C.; Zhang, D.; Wang, B.; Hou, W.; Zhou, Y. Osteopontin in Bone Metabolism and Bone Diseases. Med. Sci. Monit. 2020, 26, e919159-1. [CrossRef]

101. Rodan, G.A. Osteopontin Overview. Ann. N. Y. Acad. Sci. 1995, 760, 1-5. [CrossRef] [PubMed] 
102. Yokosaki, Y.; Matsuura, N.; Sasaki, T.; Murakami, I.; Schneider, H.; Higashiyama, S.; Saitoh, Y.; Yamakido, M.; Taooka, Y.; Sheppard, D. The Integrin $\alpha 9 \beta 1$ Binds to a Novel Recognition Sequence (SVVYGLR) in the Thrombin-cleaved Amino-terminal Fragment of Osteopontin. J. Biol. Chem. 1999, 274, 36328-36334. [CrossRef] [PubMed]

103. Green, P.M.; Ludbrook, S.B.; Miller, D.D.; Horgan, C.M.; Barry, S.T. Structural elements of the osteopontin SVVYGLR motif important for the interaction with $\alpha_{4}$ integrins. FEBS Lett. 2001, 503, 75-79. [CrossRef]

104. Rody, W.J., Jr.; Chamberlain, C.A.; Emory-Carter, A.K.; McHugh, K.P.; Wallet, S.M.; Spicer, V.; Krokhin, O.; Holliday, L.S. The proteome of extracellular vesicles released by clastic cells differs based on their substrate. PLoS ONE 2019, 14, e0219602. [CrossRef] [PubMed]

105. Scott, L.; Priestley, G.V.; Papayannopoulou, T. Deletion of $\alpha 4$ Integrins from Adult Hematopoietic Cells Reveals Roles in Homeostasis, Regeneration, and Homing. Mol. Cell. Biol. 2003, 23, 9349-9360. [CrossRef] [PubMed]

106. Priestley, G.V.; Scott, L.M.; Ulyanova, T.; Papayannopoulou, T. Lack of $\alpha 4$ integrin expression in stem cells restricts competitive function and self-renewal activity. Blood 2006, 107, 2959-2967. [CrossRef] [PubMed]

107. Ponta, H.; Sherman, L.S.; Herrlich, P.A. CD44: From adhesion molecules to signalling regulators. Nat. Rev. Mol. Cell Biol. 2003, 4, 33-45. [CrossRef]

108. Kania, J.R.; Kupfer, S.R.; Kehat-Stadler, T. CD44 Antibodies Inhibit Osteoclast Formation. J. Bone Miner. Res. 1997, 12, 1155-1164. [CrossRef] [PubMed]

109. Spessotto, P.; Rossi, F.M.; Degan, M.; Di Francia, R.; Perris, R.; Colombatti, A.; Gattei, V. Hyaluronan-CD44 interaction hampers migration of osteoclast-like cells by down-regulating MMP-9. J. Cell Biol. 2002, 158, 1133-1144. [CrossRef]

110. Chellaiah, M.A.; Kizer, N.; Biswas, R.; Alvarez, U.; Strauss-Schoenberger, J.; Rifas, L.; Rittling, S.R.; Denhardt, D.T.; Hruska, K.A. Osteopontin Deficiency Produces Osteoclast Dysfunction Due to Reduced CD44 Surface Expression. Mol. Biol. Cell 2003, 14, 173-189. [CrossRef]

111. de Vries, T.J.; Schoenmaker, T.; Beertsen, W.; van der Neut, R.; Everts, V. Effect of CD44 deficiency on in vitro and in vivo osteoclast formation. J. Cell. Biochem. 2005, 94, 954-966. [CrossRef] [PubMed]

112. Kim, H.; Takegahara, N.; Walsh, M.C.; Choi, Y. CD44 Can Compensate for IgSF11 Deficiency by Associating with the Scaffold Protein PSD-95 during Osteoclast Differentiation. Int. J. Mol. Sci. 2020, 21, 2646. [CrossRef] [PubMed]

113. Kohara, Y.; Haraguchi, R.; Kitazawa, R.; Kitazawa, S. Knockdown of Lrp1 in RAW264 cells inhibits osteoclast differentiation and osteoclast-osteoblast interactions in vitro. Biochem. Biophys. Res. Commun. 2020, 523, 961-965. [CrossRef] [PubMed]

114. Bartelt, A.; Behler-Janbeck, F.; Beil, F.T.; Koehne, T.; Müller, B.; Schmidt, T.; Heine, M.; Ochs, L.; Yilmaz, T.; Dietrich, M.; et al. Lrp1 in osteoblasts controls osteoclast activity and protects against osteoporosis by limiting PDGF-RANKL signaling. Bone Res. 2018, 6, 4. [CrossRef] [PubMed]

115. Lu, D.; Li, J.; Liu, H.; Foxa, G.E.; Weaver, K.; Li, J.; Williams, B.; Yang, T. LRP1 Suppresses Bone Resorption in Mice by Inhibiting the RANKL-Stimulated NF-кB and p38 Pathways During Osteoclastogenesis. J. Bone Miner. Res. 2018, 33, 1773-1784. [CrossRef] [PubMed]

116. Vi, L.; Baht, G.S.; Soderblom, E.J.; Whetstone, H.; Wei, Q.; Furman, B.; Puviindran, V.; Nadesan, P.; Foster, M.; Poon, R.; et al. Macrophage cells secrete factors including LRP1 that orchestrate the rejuvenation of bone repair in mice. Nat. Commun. 2018, 9, 1-12. [CrossRef] [PubMed]

117. Van Gool, B.; Dedieu, S.; Emonard, H.; Roebroek, A.J.M. The Matricellular Receptor LRP1 Forms an Interface for Signaling and Endocytosis in Modulation of the Extracellular Tumor Environment. Front. Pharmacol. 2015, 6, 271. [CrossRef] [PubMed]

118. Wujak, L.; Schnieder, J.; Schaefer, L.; Wygrecka, M. LRP1: A chameleon receptor of lung inflammation and repair. Matrix Biol. 2018, 68-69, 366-381. [CrossRef] [PubMed]

119. Holliday, L.S.; Patel, S.S. RANKL and RANK in extracellular vesicles: Surprising new players in bone remodeling. Extracell. Vesicles Circ. Nucleic Acids 2021, 2, 18-28. [CrossRef]

120. Deng, L.; Wang, Y.; Peng, Y.; Wu, Y.; Ding, Y.; Jiang, Y.; Shen, Z.; Fu, Q. Osteoblast-derived microvesicles: A novel mechanism for communication between osteoblasts and osteoclasts. Bone 2015, 79, 37-42. [CrossRef]

121. Cappariello, A.; Loftus, A.; Muraca, M.; Maurizi, A.; Rucci, N.; Teti, A. Osteoblast-Derived Extracellular Vesicles Are Biological Tools for the Delivery of Active Molecules to Bone. J. Bone Miner. Res. 2018, 33, 517-533. [CrossRef]

122. Huynh, N.; VonMoss, L.; Smith, D.; Rahman, I.; Felemban, M.; Zuo, J.; Rody, J.W.; McHugh, K.; Holliday, L. Characterization of Regulatory Extracellular Vesicles from Osteoclasts. J. Dent. Res. 2016, 95, 673-679. [CrossRef] [PubMed]

123. Li, D.; Liu, J.; Guo, B.; Liang, C.; Dang, L.; Lu, C.; He, X.; Cheung, H.Y.-S.; Xu, L.; Lu, C.; et al. Osteoclast-derived exosomal miR-214-3p inhibits osteoblastic bone formation. Nat. Commun. 2016, 7, 10872. [CrossRef]

124. Sun, W.; Zhao, C.; Li, Y.; Wang, L.; Nie, G.; Peng, J.; Wang, A.; Zhang, P.; Tian, W.; Li, Q.; et al. Osteoclast-derived microRNAcontaining exosomes selectively inhibit osteoblast activity. Cell Discov. 2016, 2, 16015. [CrossRef]

125. Wortzel, I.; Dror, S.; Kenific, C.M.; Lyden, D. Exosome-Mediated Metastasis: Communication from a Distance. Dev. Cell 2019, 49, 347-360. [CrossRef] [PubMed]

126. Hurwitz, S.N.; Meckes, D.G., Jr. Extracellular Vesicle Integrins Distinguish Unique Cancers. Proteomes 2019, 7, 14. [CrossRef] [PubMed]

127. Xie, X.; Lian, S.; Zhou, Y.; Li, B.; Lu, Y.; Yeung, I.; Jia, L. Tumor-derived exosomes can specifically prevent cancer metastatic organotropism. J. Control. Release 2021, 331, 404-415. [CrossRef]

128. Sung, B.H.; Ketova, T.; Hoshino, D.; Zijlstra, A.; Weaver, A.M. Directional cell movement through tissues is controlled by exosome secretion. Nat. Commun. 2015, 6, 7164. [CrossRef] [PubMed] 
129. Hoshino, D.; Kirkbride, K.C.; Costello, K.; Clark, E.S.; Sinha, S.; Grega-Larson, N.; Tyska, M.J.; Weaver, A.M. Exosome Secretion Is Enhanced by Invadopodia and Drives Invasive Behavior. Cell Rep. 2013, 5, 1159-1168. [CrossRef]

130. Sung, B.H.; Weaver, A.M. Exosome secretion promotes chemotaxis of cancer cells. Cell Adhes. Migr. 2017, 11, 187-195. [CrossRef]

131. Murray, J.B.; Mikhael, C.; Han, G.; de Faria, L.P.; Rody, W.J.; Holliday, L.S. Activation of (pro)renin by (pro)renin receptor in extracellular vesicles from osteoclasts. Sci. Rep. 2021, 11, 1-8. [CrossRef]

132. Tzaridis, T.; Reiners, K.S.; Weller, J.; Bachurski, D.; Schäfer, N.; Schaub, C.; Hallek, M.; Scheffler, B.; Glas, M.; Herrlinger, U.; et al. Analysis of Serum miRNA in Glioblastoma Patients: CD44-Based Enrichment of Extracellular Vesicles Enhances Specificity for the Prognostic Signature. Int. J. Mol. Sci. 2020, 21, 7211. [CrossRef] [PubMed]

133. Holliday, L.S.; Lu, M.; Lee, B.S.; Nelson, R.D.; Solivan, S.; Zhang, L.; Gluck, S.L. The Amino-terminal Domain of the B Subunit of Vacuolar H+-ATPase Contains a Filamentous Actin Binding Site. J. Biol. Chem. 2000, 275, 32331-32337. [CrossRef]

134. Zhao, H.; Ito, Y.; Chappel, J.; Andrews, N.W.; Teitelbaum, S.L.; Ross, F.P. Synaptotagmin VII Regulates Bone Remodeling by Modulating Osteoclast and Osteoblast Secretion. Dev. Cell 2008, 14, 914-925. [CrossRef]

135. MacDougall, D.D.; Lin, Z.; Chon, N.L.; Jackman, S.L.; Lin, H.; Knight, J.D.; Anantharam, A. The high-affinity calcium sensor synaptotagmin-7 serves multiple roles in regulated exocytosis. J. Gen. Physiol. 2018, 150, 783-807. [CrossRef]

136. Volynski, K.E.; Krishnakumar, S.S. Synergistic control of neurotransmitter release by different members of the synaptotagmin family. Curr. Opin. Neurobiol. 2018, 51, 154-162. [CrossRef]

137. Yadav, K.S.; Astudillo, H.V.M.; Colina-Tenorio, L.; Bouillenne, F.; Degand, H.; Morsomme, P.; González-Halphen, D.; Boekema, E.J.; Cardol, P. Atypical composition and structure of the mitochondrial dimeric ATP synthase from Euglena gracilis. Biochim. Biophys. Acta Bioenerg. 2017, 1858, 267-275. [CrossRef] [PubMed]

138. Delgado-Calle, J.; Tu, X.; Pacheco-Costa, R.; McAndrews, K.; Edwards, R.; Pellegrini, G.G.; Kuhlenschmidt, K.; Olivos, N.; Robling, A.; Peacock, M.; et al. Control of Bone Anabolism in Response to Mechanical Loading and PTH by Distinct Mechanisms Downstream of the PTH Receptor. J. Bone Miner. Res. 2016, 32, 522-535. [CrossRef] [PubMed]

139. Phillips, J.A.; Almeida, E.A.; Hill, E.L.; Aguirre, J.I.; Rivera, M.F.; Nachbandi, I.; Wronski, T.J.; Van Der Meulen, M.C.H.; Globus, R.K. Role for $\beta 1$ integrins in cortical osteocytes during acute musculoskeletal disuse. Matrix Biol. 2008, $27,609-618$. [CrossRef] [PubMed]

140. Litzenberger, J.B.; Kim, J.-B.; Tummala, P.; Jacobs, C.R. $\beta 1$ Integrins Mediate Mechanosensitive Signaling Pathways in Osteocytes. Calcif. Tissue Int. 2010, 86, 325-332. [CrossRef]

141. Mizoguchi, F.; Mizuno, A.; Hayata, T.; Nakashima, K.; Heller, S.; Ushida, T.; Sokabe, M.; Miyasaka, N.; Suzuki, M.; Ezura, Y.; et al. Transient receptor potential vanilloid 4 deficiency suppresses unloading-induced bone loss. J. Cell. Physiol. 2008, 216, 47-53. [CrossRef]

142. Papachroni, K.K.; Karatzas, D.N.; Papavassiliou, K.A.; Basdra, E.K.; Papavassiliou, A.G. Mechanotransduction in osteoblast regulation and bone disease. Trends Mol. Med. 2009, 15, 208-216. [CrossRef] [PubMed]

143. Zhang, X.-Z.; Xu, X.-Y.; Guo, C.; Yan, Y.-X.; Li, R.-X.; Song, M. Differential effects of mechanical strain on osteoclastogenesis and osteoclast-related gene expression in RAW264.7 cells. Mol. Med. Rep. 2012, 6, 409-415. [CrossRef] [PubMed]

144. Suzuki, N.; Yoshimura, Y.; Deyama, Y.; Suzuki, K.; Kitagawa, Y. Mechanical stress directly suppresses osteoclast differenti-ation in RAW264.7 cells. Int. J. Mol. Med. 2008, 21, 291-296. [PubMed]

145. Kulkarni, R.N.; Voglewede, P.A.; Liu, D. Mechanical vibration inhibits osteoclast formation by reducing DC-STAMP receptor expression in osteoclast precursor cells. Bone 2013, 57, 493-498. [CrossRef] [PubMed] 